\title{
EGG ALBUMIN AND MILK MIXTURE AS A NEW STORAGE MEDIUM TO PRESERVE VITALITY OF PERIODONTAL LIGAMENTS OF INTENTIONALLY EXTRACTED ANIMAL TEETH
}

\author{
Hamid $\mathrm{M}^{*}$, Alaa Abdallah ${ }^{* *}$, Elyazeed GA ${ }^{* * *}$, Abo El Yazeed $\mathrm{M}^{* * * *}$ and Elbayoumy S. ${ }^{* * * * *}$
}

\section{ABSTRACT}

\begin{abstract}
Aim: This study aimed to evaluate egg albumin and milk mixture as a new storage medium to preserve vitality of PDL of avulsed teeth. Materials and Media: 180 incisors of 45 New Zealand rabbits were atraumatically extracted and divided into 4 equal groups (45 teeth). Gr.1 and 3 teeth were equally divided into 3 subgroups (15 teeth for each) and stored immediately post extraction in HBSS \& EAMM for 1,4 \& 6h respectively. By the same manner Gr.2 and Gr. 4 were equally divided and stored after $1 \mathrm{~h}$ dry time in HBSS \& EAMM for $1,4 \& 6 \mathrm{~h}$ respectively. Then the teeth were removed and prepared for histological investigation \& digital counting of PDL cells using trypan blue exclusion technique. Results: Teeth stored in HBSS immediately showed that $65.75 \%, 48.25 \%$ \& $38.08 \%$ of PDL cells were vital after 1, $4 \& 6$ h storage time respectively, while EAMM reported $49 \%, 50.06 \&$ $47.67 \%$ for the same storage times. On the other hand teeth stored in EAMM after 1 h dry time showed that $30.672 \%, 34.665 \%$ And $36.011 \%$ of PDL cells were vital after 1, 4 \& $6 \mathrm{~h}$ storage time respectively, while EAMM reported $45.582 \%, 50.79 \%$ and $45.78 \%$ for the same storage times Conclusion: EAMM has proved powerful higher results than HBSS in all storage times $(1,4$ and $6 \mathrm{~h})$ in $1 \mathrm{~h}$ dry time which is an evidence of its ability of replenishment of metabolites in depleted PDL cells and it can be used at trauma sites specially when immediate replantation is not available.
\end{abstract}

\section{INTRODUCTION}

Tooth avulsion is a term used to describe a tooth completely removed from its socket as a result of trauma ${ }^{(1)}$. It represents a potential threat for affected teeth periodontium and pulp cells so it requires quick emergency intervention or immediate replantation ${ }^{(2)}$.If immediate replantation is not available, maintenance of the avulsed tooth in a compatible storage medium to keep these cells survival before replantation in the socket is a must ${ }^{(3)}$. Many of storage media were suggested as saline, artificial saliva and Hank's Balanced Salt Solution. Other alternative natural storage media were suggested as Milk which indicated by (AAE) as a solution for avulsed teeth ${ }^{(4)}$. Egg albumin is another alternative which showed good incidence of repair up to 10h when used to store PDL of avulsed teeth $^{(5)}$. Studies suggest that they can be perfect media for storing avulsed teeth but they need additional studies. Up till now approximately there are no studies on egg albumin and milk mixture so this study will investigate this new mix as a storage medium for PDL cells of avulsed teeth.

\footnotetext{
* Research Assistant at National Research Center, Oral and Dental Medicine Division, Department of Orthodontics and Pedodontics, Egypt

*** Lecturer of Pediatric Dentistry and Dental Public Health, Faculty of Dental Medicine (Boys-Cairo), Al-Azhar University, Egypt

*** Lecturer of Oral Biology, Faculty of Dental Medicine (Boys-Cairo), Al-Azhar University, Egypt

**** Professor at National Research Center, Oral and Dental Medicine Division, and head of department of Orthodontics and Pedodontics, Egypt

***** Professor and head of Pediatric Dentistry and Dental Public Health Department, Faculty of Dental Medicine (Boys-Cairo), Al-Azhar University, Egypt
} 


\section{MATERIALS AND METHODS}

\section{Samples selection and preparation}

Rabbits were used and clinical pattern of avulsion were simulated. Forty five New Zealand rabbits (age range was 5 months) randomly selected and the four incisors were extracted atraumatically All rabbits were anaesthetized according to Cornell University Institutional Animal Care and Use Committee rabbit anesthesia protocol ${ }^{(6)}$. Using xylazine** $^{*} 1-5 \mathrm{mg} / \mathrm{Kg}$ IM which gave $30-60$ min working time and the two upper and two lower incisors were atraumatically extracted using a Periotome ${ }^{(7)}$

\section{Materials}

Two storage media were used:

(1) Hanks balanced salt solution (HBSS)* .

(2) Egg albumin and milk mixture $1: 1$ by volume (pH 6.6-7.8)

HBSS is composed of sodium chloride; D-glucose; potassium chloride; sodium bicarbonate; sodium phosphate; potassium phosphate; calcium Chloride; magnesium chloride and Magnesium Sulfate ${ }^{(2)}$.

Egg albumin is mainly composed of water, proteins, carbohydrates, minerals, vitamins and sugars ${ }^{(8)}$.

Milk is also composed of water, protein, carbohydrate, minerals, vitamins, and Fatty acids. ${ }^{(9)}$

\section{Teeth classifications}

The extracted teeth (180) were classified according to 3 factors:

\section{1-Storage medium.}

The extracted teeth were classified randomly into two major groups (90 teeth for each $n=90$ ) according to type of storage medium.

Gr.1: HBSS.

\section{2-Dry time.}

Each main group was divided into two equal subgroups (45 teeth) according to dry time $(n=45)$.

Sub. A: Immediate replantation. Sub. B: 1h dry time post extraction before storage.

\section{3-Storage time inside the medium.}

Each subgroup was further subdivided into three subdivisions according to storage time inside the storage medium in normal room temperature (with 15 teeth for each $n=15$ ).
A. 1h.
B. $4 \mathrm{~h}$.
C. $6 \mathrm{~h}$.

TABLE 1: Variables interactions of the study:

\begin{tabular}{|c|c|c|c|c|}
\hline \multicolumn{2}{|c|}{$\begin{array}{c}1(\mathrm{Gr} .1) \\
(\mathrm{n}=90)\end{array}$} & \multicolumn{2}{|c|}{$\begin{array}{c}2 \text { (Gr.2) } \\
(\mathrm{n}=90)\end{array}$} & \multirow[t]{2}{*}{ Total } \\
\hline $\begin{array}{c}\text { A (Gr.1 sub. } \\
\text { A) } \\
(\mathrm{n}=45)\end{array}$ & $\begin{array}{l}\text { B }(\mathrm{Gr} .1 \\
\text { sub.B) } \\
(\mathrm{n}=45)\end{array}$ & $\begin{array}{l}\text { A }(\mathrm{Gr} .2 \\
\text { sub.A) } \\
(\mathrm{n}=45)\end{array}$ & $\begin{array}{l}\text { B }(\mathrm{Gr} .2 \\
\text { sub.B) } \\
(\mathrm{n}=45)\end{array}$ & \\
\hline $\begin{array}{c}1 \mathrm{~h} \\
(1 \mathrm{~A} 1 \mathrm{~h}) \\
\mathrm{n}=15\end{array}$ & $\begin{array}{c}1 \mathrm{~h} \\
(1 \mathrm{~B} 1 \mathrm{~h}) \\
\mathrm{n}=15\end{array}$ & $\begin{array}{c}1 \mathrm{~h} \\
(2 \mathrm{~A} 1 \mathrm{~h}) \\
\mathrm{n}=15\end{array}$ & $\begin{array}{c}1 \mathrm{~h} \\
(2 \mathrm{~B} 1 \mathrm{~h}) \\
\mathrm{n}=15\end{array}$ & \\
\hline $\begin{array}{c}4 \mathrm{~h} \\
(1 \mathrm{~A} 4 \mathrm{~h}) \\
\mathrm{n}=15\end{array}$ & $\begin{array}{c}4 \mathrm{~h} \\
(1 \mathrm{~B} 4 \mathrm{~h}) \\
\mathrm{n}=15\end{array}$ & $\begin{array}{c}4 \mathrm{~h} \\
(2 \mathrm{~A} 4 \mathrm{~h}) \\
\mathrm{n}=15\end{array}$ & $\begin{array}{c}4 \mathrm{~h} \\
(2 \mathrm{~B} 4 \mathrm{~h}) \\
\mathrm{n}=15\end{array}$ & \\
\hline $\begin{array}{c}6 \mathrm{~h} \\
(1 \mathrm{~A} 6 \mathrm{~h}) \\
\mathrm{n}=15\end{array}$ & $\begin{array}{c}6 \mathrm{~h} \\
(1 \mathrm{~B} 6 \mathrm{~h}) \\
\mathrm{n}=15\end{array}$ & $\begin{array}{c}6 \mathrm{~h} \\
(2 \mathrm{~A} 6 \mathrm{~h}) \\
\mathrm{n}=15\end{array}$ & $\begin{array}{c}6 \mathrm{~h} \\
(2 \mathrm{~B} 6 \mathrm{~h}) \\
\mathrm{n}=15\end{array}$ & \\
\hline
\end{tabular}

\section{Histological examination}

After storage at room temperature $27 \mathrm{C}$, teeth were grasped from their crowns, washed with saline and put into $10 \%$ formalin. The PDL of extracted teeth were removed from roots using sharp curette $3 \mathrm{~mm}$ apical to CEJ to exclude damaged PDL from the extraction forceps. The removed fibers were stained Trypan Blue Exclusion Technique. The viable and non-viable cells were counted using digital

\footnotetext{
* Save-A-Tooth; Phoenix Lazerus Inc., Pottstown, PA, USA. ** Xyla-Ject injectable sol. ADWIA Co.S.A.E Egypt.
} 
microscope with magnification X 200 with a corresponding special software in area 121 x $129 \mathrm{Mm}$ for each slide in General Pathology Laboratory of National Research Center ${ }^{(5,10,11)}$.

\section{Statistical analysis}

Data were collected and analyzed using SPSS.16 statistical software (IBM Corp., Armonk, N.Y., USA). Data were analyzed by one way analysis of variance (ANOVA), post hoc Tukey and paired t-test at significance level of $\mathrm{P}<0.05$.

\section{RESULTS}

HBSS showed better results on storage of PDL cells for $1 \mathrm{~h}$ immediately after extraction than the new EAMM with a significant difference. However, on storage for $4 \mathrm{~h}$ there was no significant difference between the two media, meanwhile on storage for $6 \mathrm{~h}$ EAMM showed better results than HBSS with a highly significant difference but, EAMM showed better preservation of vitality of stored cells for 1 , 4 and $6 \mathrm{~h}$ after dry time for $1 \mathrm{~h}$ post extraction than HBSS with a highly significant difference when compared statistically as following:

TABLE 2: Comparison of the time factor effect on PDL cells of teeth immediately and after $1 \mathrm{~h}$ dry time post extraction stored in both storage media (EAMM and HBSS storage media):

\begin{tabular}{|c|c|c|c|c|c|c|}
\hline \multicolumn{7}{|c|}{ Teeth immediately stored post extraction } \\
\hline Character & Media & Mean \% & Mean difference & St.deviation & St.error & Sig. \\
\hline \multirow{2}{*}{ 1h storage time } & HBSS & $65.733 \%$ & \multirow{2}{*}{ \pm 16.747} & \pm 7.847 & \pm 2.026 & \multirow{2}{*}{$\mathrm{P}=0.000$} \\
\hline & EAMM & $49.003 \%$ & & \pm 3.218 & \pm 0.831 & \\
\hline \multirow{2}{*}{ 4h storage time } & HBSS & $48.333 \%$ & \multirow{2}{*}{ \pm 1.812} & \pm 9.22 & \pm 2.38 & \multirow{2}{*}{$\mathrm{P}=0.373$ N.S } \\
\hline & EAMM & $50.064 \%$ & & \pm 1.957 & \pm 0.505 & \\
\hline \multirow{2}{*}{$6 \mathrm{~h}$ storage time } & HBSS & $38.084 \%$ & \multirow{2}{*}{ \pm 9.985} & \pm 3.932 & \pm 1.015 & \multirow{2}{*}{$\mathrm{P}=0.000$} \\
\hline & EAMM & $47.673 \%$ & & \pm 2.778 & \pm 0.717 & \\
\hline \multicolumn{7}{|c|}{ Teeth stored after $1 \mathrm{~h}$ dry time post extraction } \\
\hline \multirow{2}{*}{ 1h storage time } & HBSS & $30.672 \%$ & \multirow{2}{*}{ \pm 15.108} & \pm 5.325 & \pm 1.375 & \multirow[b]{2}{*}{$\mathrm{P}=0.000$} \\
\hline & EAMM & $45.78 \%$ & & \pm 2.98 & \pm 0.77 & \\
\hline \multirow{2}{*}{ 4h storage time } & HBSS & $34.665 \%$ & \multirow{2}{*}{ \pm 16.124} & \pm 5.026 & \pm 1.297 & \multirow[b]{2}{*}{$\mathrm{P}=0.000$} \\
\hline & EAMM & $50.79 \%$ & & \pm 4.032 & \pm 1.041 & \\
\hline \multirow{2}{*}{$6 \mathrm{~h}$ storage time } & HBSS & $36.011 \%$ & \multirow{2}{*}{ \pm 9.57} & \pm 3.849 & \pm 0.993 & \multirow[b]{2}{*}{$\mathrm{P}=0.000$} \\
\hline & EAMM & $45.582 \%$ & & \pm 6.785 & \pm 1.751 & \\
\hline
\end{tabular}




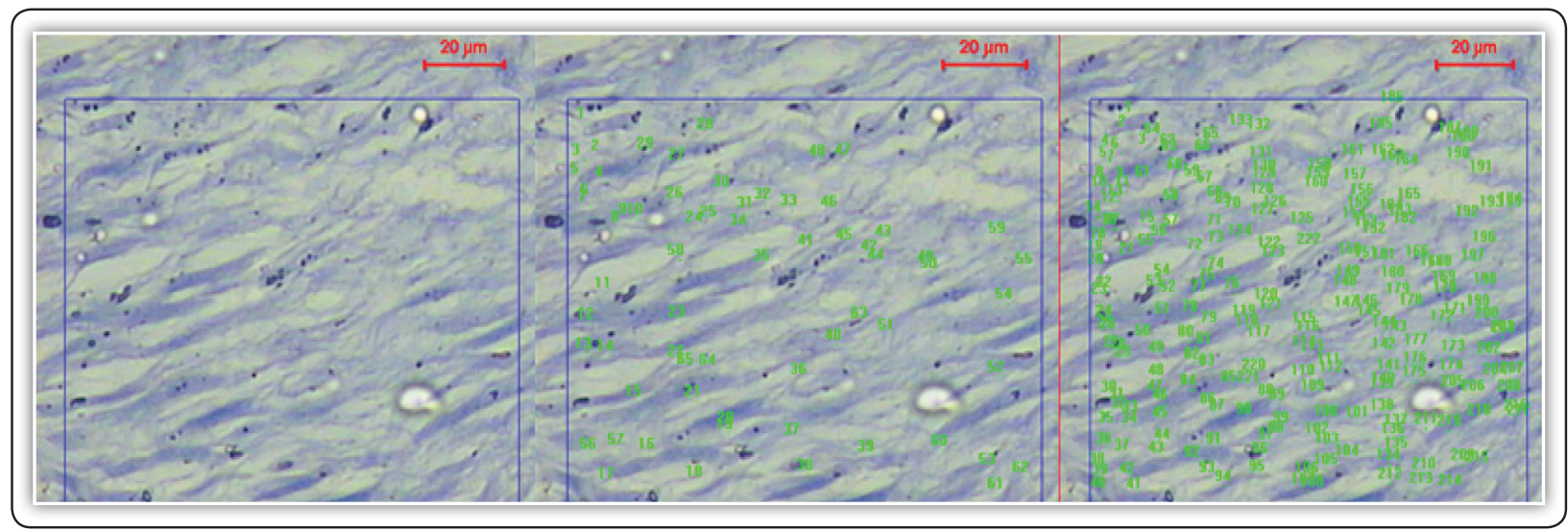

FIG (1) Photomicrograph showing in the first square the original slide, the middle square showing counted viable cells (red arrow) and the last square showing counted non-viable (black arrow) fibroblasts of PDL of a tooth (X 200) with a corresponding special software in area $121 \times 129 \mathrm{Mm}$.

\section{DISCUSSION}

Maintenance of the avulsed tooth in a compatible storage medium till replantation is the key of success of healing ${ }^{(3)}$. HBSS was considered the best for preservation of vitality of PDL cells of avulsed tooth. However, it is expensive and not available easily at trauma sites ${ }^{(12)}$.

On storage of teeth immediately post extraction in HBSS for $1 \mathrm{~h}$ it was found that about $65.73 \%$ of cells were vital in agreement with Krasner p. et al who stated that HBSS maintain a superior success rate if an avulsed tooth is soaked in it for 30 minutes $^{(13)}$.

On storage immediately post extraction in HBSS for 4 and $6 \mathrm{~h}$ it was found that about 48.33 $\%$ and $37.86 \%$ of cells were viable respectively. The decreased number of viable cells compared to $1 \mathrm{hr}$ storage time may be due to beginning of loss of water specially storage of PDL cells of this study was in room temperature not in refrigerated conditions to mimic clinical process of avulsion. Moreover, it may be due to consumption of needed contents of minerals that HBSS is rich of it but it still challenge for viability as there is no total cell death ${ }^{(13,14)}$.
Investigation of number of vital cells of PDL of teeth showed less number of vital cells after 1h dry time post extraction. It reported that about $30.6 \%$ of cells only were vital after $1 \mathrm{~h}$ storage time in HBSS. It was challenging for HBSS due to beginning of cell death after $15 \mathrm{~min}$ of dry storage according to Lekic P. et al and also in agreement with Layung ML. et al who mentioned that after 30 min of dry storage, virtually all of the PDL cells remaining on the tooth are dead ${ }^{(4,15)}$.

Storage of cells in HBSS for 4 and $6 \mathrm{~h}$ after one hour dry time post extraction showed that about $34.66 \%$ and $36 \%$ of cells respectively were vital which indicates that HBSS has the ability to replenish metabolites in depleted PDL cells because number of vital cells has increased after storage for more time and this became in agreement with Fagade O. et al and Krasner and Rankow. However, in the present study it seems that this ability is quietly limited as there was no significant difference statistically between two storage times ${ }^{(16,17)}$.

The new EAMM has no previous studies for its effect on viability of PDL cells but each of them has a scientific evidence of use as a solo storage medium but with different results as they were tested under different conditions. 
Storage in EAMM for $1 \mathrm{~h}$ immediately post extraction of teeth showed that about $49 \%$ cells viability which was inferior to HBSS $65.733 \%$ at the same conditions and it comes in contrast to Martins et al. who approved that Milk was better than all other storage media by evaluation of human PDL cells which resulted in $87 \%$ cell viability after $24 \mathrm{~h}$ of incubation ${ }^{(18)}$.

De souza, B. et al Stated in their study that whole milk showed better results with a significant difference than HBSS for storage of PDL for 3, 6 and 24 hours and this comes in partial agreement with our study as the new mixture showed better results in storage for $6 \mathrm{~h}$ but in contrast in their study they tested storage for 48, 72, 96 and $120 \mathrm{~h}$ and surprisingly HBSS was the best storage medium in comparison to Whole Milk, Skimmed Milk, Egg White, Coconut water and Propolis ${ }^{(19)}$.

Storage of cells in EAMM for $1 \mathrm{~h}$ after $1 \mathrm{~h}$ dry time post extraction showed that $45.8 \%$ cells vitality which was superior to HBSS with $30.6 \%$ cell viability with a high significant difference which proves that there is a high ability of cell revitalization.

Storage of cells in EAMM for $4 \mathrm{~h}$ and $6 \mathrm{~h}$ respectively after $1 \mathrm{~h}$ dry time post extraction showed that about $50.73 \%$ and $45.46 \%$ of cells respectively were vital which showed high significant difference when compared to HBSS results at the same conditions, moreover on comparison between results of EAMM for $1 \mathrm{~h}$ and $4 \mathrm{~h}(45.8 \%$ \& $50.73 \%)$ which support the idea of vitality preservation of the new mix but, results return back inferiorly on storage for $6 \mathrm{~h}(45.46 \%)$ may be due to consumption of contents of milk and egg albumin by the PDL cells after this long time of storage but still better than results of HBSS. These groups' results together with the results of immediate storage groups support the concept of that Egg albumin \& Milk novel mixture has the ability of replenishment of metabolites in depleted cells more than the previously approved evidence of $\operatorname{HBSS}{ }^{(16,17)}$.

\section{REFERENCES}

1. Eskandrian T, Badaghsh H, Esmaeilpour H. The effectiveness of oral rehydration solution at various concentrations as a storage media for avulsed teeth. Iran Endod J. 2013; 8: $22-24$

2. Gomes M, Westphalen V, Westphalen F, Neto U, Fariniuk L, Carniero E. Study of storage media for avulsed teeth. Brazilian J of Dent Traumatol 2009; 1: 69-76.

3. Goswami M, Chaitra T, Chaudhary S, Manuja N, Sinha A. Strategies for periodontal ligament cell viability: An overview. J Conserv Dent. 2011; 14: 215-20

4. Lekic PC, Kenny DJ, Barrett EJ. The influence of storage conditions on the clonogenic capacity of periodontal ligament cells: implications for tooth replantation. Int Endod J 1998; 31: 137-40

5. Khademi AA, Saei S, Mohajeri MR et al. A new storage medium for an avulsed tooth. J Contemp Dent Pract 2008; 9: $25-32$.

6. Martin M., Kirsipuu V. ACUP 103.01 Rabbit Anesthesia Cornell University Institutional Animal Care and Use Committee Jan. 2014.

7. Udoye C, Jafarzadeh H, Abbott P. Transport media for avulsed teeth: A review. Aust Endod J 2012; 38: 129-136.

8. United States Department of Agriculture, Agricultural Research Service National Nutrient Database for Standard Reference Release 26.

9. USDA National Nutrient Database for Standard Reference Release 26. Basic Report 01076, Milk substitutes, fluid, with lauric acid oil. Report Date: August 01, 2014 15:55 EDT.

10. Moazami F, Mirhadi H, Geramizadeh B, Sahebi S. Comparison of soymilk, powdered milk, Hank's balanced salt solution and tap water on periodontal ligament cell survival. Dent Traumatol.2012; 28: 132-5.

11. Doyle D, Dumsha T, Sydiskis R. Effect of soaking in Hank's balanced salt solution or milk on PDL cell viability of dry stored human teeth Endod Dent Traumatol. 1998; 14: $221-4$

12. Ashkenazi $\mathrm{M}$, Sarnat $\mathrm{H}$, Keila S. In vitro viability, mitogenicity and clonogenic capacity of periodontal ligament cells after storage in six different media. Dent Traumatol, 1999; 15: 149-56. 
13. Krasner P. 1992. Tooth avulsion in the school setting. J Sch Nurs, 8: 20-6.

14. Ashkenazi M, Marouni M, Sarnat H. In vitro viability, mitogenicity and clonogenic capacity of periodontal ligament cells after storage in four media at room temperature. Dent Traumatol 2000; 16: 63-70.

15. Layug ML, Barrett EJ, Kenny DJ. Interim storage of avulsed permanent teeth. J Can Dent Assoc 1998; 64: 357-63. 365-9.

16. O Fagade. Extra-Alveolar Storage Media for Tooth Autotransplants and Replants. The Internet Journal of Dental Science 2004; 2 Number 2.

17. Krasner P, Rankow HJ. New philosophy for the treatment of avulsed teeth. Oral Surg Oral Med Oral Pathol Oral Radiol Endod 1995; 79: 616-23. 